\title{
In Vitro and In Vivo Activation of Mitochondrial Membrane Permeability Transition Pore Using Triiodothyronine
}

\author{
R. ENDLICHER ${ }^{1,2}$, Z. DRAHOTA ${ }^{1,3}$, Z. ČERVINKOVÁ ${ }^{1}$
}

${ }^{1}$ Department of Physiology, Charles University in Prague, Faculty of Medicine in Hradec Králové, Czech Republic, ${ }^{2}$ Department of Anatomy, Charles University in Prague, Faculty of Medicine in Hradec Králové, Czech Republic, ${ }^{3}$ Institute of Physiology of the Czech Academy of Sciences, Prague, Czech Republic

Received March 19, 2015

Accepted July 1, 2015

On-line October 8, 2015

\begin{abstract}
Summary
Using a novel method for evaluating mitochondrial swelling (Drahota et al. 2012a) we studied the effect of calcium $\left(\mathrm{Ca}^{2+}\right)$, phosphate $\left(\mathrm{P}_{\mathrm{i}}\right)$, and triiodothyronine $\left(\mathrm{T}_{3}\right)$ on the opening of mitochondrial membrane permeability transition pore and how they interact in the activation of swelling process. We found that $0.1 \mathrm{mM} \mathrm{P}_{\mathrm{i}}, 50 \mu \mathrm{M} \mathrm{Ca}{ }^{2+}$ and $25 \mu \mathrm{M} \mathrm{T} \mathrm{T}_{3}$ when added separately increase the swelling rate to about $10 \%$ of maximal values when all three factors are applied simultaneously. Our findings document that under experimental conditions in which $\mathrm{Ca}^{2+}$ and $P_{i}$ are used as activating factors, the addition of $T_{3}$ doubled the rate of swelling. $T_{3}$ has also an activating effect on mitochondrial membrane potential. The $T_{3}$ activating effect was also found after in vivo application of $T_{3}$. Our data thus demonstrate that $T_{3}$ has an important role in opening the mitochondrial membrane permeability pore and activates the function of the two key physiological swelling inducers, calcium and phosphate ions.
\end{abstract}

\section{Key words}

Rat liver mitochondria • Membrane permeability transition pore • Thyroid hormones

\section{Corresponding author}

Z. Červinková, Department of Physiology, Charles University in Prague, Faculty of Medicine in Hradec Králové, Šimkova 870, 50038 Hradec Králové, Czech Republic.

E-mail: wolff@lfhk.cuni.cz

\section{Introduction}

Thyroid hormones play an important role as modulators of cell energy expenditure and thermogenesis. Their effect was explained as the uncoupling of mitochondrial oxidative phosphorylation (Harper and Seifert 2008). The mechanism of thyroid hormone action on cell bioenergetics is very complex (Harper and Seifert 2008, Davis and Davis 1996, Guerrieri et al. 1998, Zhang and Lazar 2000, Lanni et al. 2001, Mráček et al. 2005, Cheng et al. 2010). Their direct action on mitochondria can be seen through energy dissipation and also through mitochondrial swelling induced by activation of water transport to mitochondria (Raaflaub 1953, Tapley 1956, Lehninger 1960). When the membrane permeability transition pore (MPTP) was discovered to be an important mechanism in activating cell apoptotic processes, it was also demonstrated that this pore is involved in the pathogenesis of diseases such as cardiomyopathies, neuropathies, liver diseases and diabetes (Rasola and Bernardi 2011, Halestrap and Richardson 2015, Bernardi and Di Lisa 2015, Karch and Molkentin 2014). Attention has also been paid to characterizing the many factors that modulate MPTP function in various organs (Crompton et al. 1988, Halestrap and Richardson 2015), factors including thyroid hormones (Kalderon et al. 1995, Castilho et al. 1998, Venditti et al. 2003, Yehuda-Shnaidman et al. 2010). However, in spite of the great effort made by researchers, the molecular mechanism of MPTP function as well as the mechanism through which various factors, including thyroid hormones, can regulate its gating have remained obscure (Yehuda-Shnaidman et al. 2014).

There are several reasons why the mechanism of 
triiodothyronine $\left(\mathrm{T}_{3}\right)$ action on MPTP function is so difficult to unravel, the first of which is the fact that MPTP is defined only through its function, i.e. as Ca-activated cyclosporine-inhibited mitochondrial swelling. However, the structural arrangement of MPTP has yet to be precisely defined. It is known that the pore is formed by many protein subunits; however, their number is continuously increasing (Vianello et al. 2012, Karch and Molkentin 2014) and some of them have also been dismissed as adenine nucleotide translocator (Kokoszka et al. 2004) or phosphate translocator (Gutiérrez-Aguilar et al. 2014), when genetically modified mice without particular protein were accessible. Some authors have even proposed a role for ATP synthasome component subunit $\mathrm{c}$ in the pore structure and function (Alavian et al. 2014).

It is therefore very difficult to localize the target of $\mathrm{T}_{3}$ action and analyze interactions between factors participating in the regulation of the pore opening. Another problem in these studies is that the main method used for evaluating MPTP function is now more than 60 years old and presents information about the swelling process only in graphical form. A useful method estimating the calcium retention capacity using fluorescent probe calcium green was introduced (Fontaine et al. 1998). This method gives important additional information about the swelling process but fails to provide in the digital form values of maximum swelling rate required for comparative studies of the various factors of action and interaction.

In our previous paper we tried to improve the classical method for measuring mitochondrial swelling (Drahota et al. 2012a). Merely by taking the simple derivative of the classical swelling curve we obtained two additional parameters in digital form which characterized the swelling process: the maximum swelling rate $\left(\mathrm{dA}_{520} / 10 \mathrm{~s}\right)$ and the time $(\mathrm{s})$ required to reach the maximum rate. The extent of the swelling $\left(\mathrm{dA}_{520} / 9 \mathrm{~min}\right)$ can be calculated from classical swelling curves.

Using this novel method enabled better characterization of the differences in the swelling process of mitochondria isolated from various organs (Drahota et al. 2012b) or age-dependent changes (Milerová et al. 2010).

In this paper we concentrated our attention on evaluating the effect of $\mathrm{T}_{3}$ on MPTP regulation. On isolated rat liver mitochondria we tested interactions between calcium and phosphate ions and $T_{3}$ in the regulation of pore opening using three parameters characterizing the swelling process.

\section{Methods}

\section{Chemicals}

All chemicals used were of the highest commercially available purity from Sigma (Sigma Aldrich Co. Germany).

\section{Animals}

Male Wistar rats (BioTest Konárovice, Czech Republic) weighing 220-250 g were used for the experiments. The rats were housed at $23 \pm 1{ }^{\circ} \mathrm{C}, 55 \pm 10 \%$ humidity, and air exchange 12-14 times/h and $12 \mathrm{~h}$ lightdark cycle period. The animals had free access to a standard laboratory diet (ST-1, Velaz, Czech Republic) and tap water. In in vivo experiments triiodothyronine dissolved in saline was administered intraperitoneally in a single dose or in three doses at 24-h intervals at a concentration of $200 \mu \mathrm{g} / \mathrm{kg}$ body weight. Control rats received an equivalent amount of saline solution. All rats were sacrificed $24 \mathrm{~h}$ after the final administration of triiodothyronine or saline. All animals received care according to the guidelines set by the Animal-Welfare Body of the Charles University, Prague, Czech Republic, and the International Guiding Principles for Biomedical Research Involving Animals. The animals were sacrificed in a light ether narcosis by exsanguination from aortic bifurcation. The livers were removed, washed in a cold isolation medium, and cut into small pieces.

\section{Isolation of mitochondria}

Mitochondria were isolated as described previously (Drahota et al. 2014). The cut and washed tissue was homogenized at $0{ }^{\circ} \mathrm{C}$ by a teflon-glass homogenizer in an isolation medium containing $220 \mathrm{mM}$ D-mannitol, $70 \mathrm{mM}$ sucrose, $2 \mathrm{mM}$ HEPES, $0.2 \mathrm{mM}$ EGTA, and $0.5 \mathrm{mg}$ of fatty acid free bovine serum albumin (BSA) per $\mathrm{ml}$, with a $\mathrm{pH}$ of 7.2 . The $5 \%$ homogenate was centrifuged for $10 \mathrm{~min}$ at $600 \mathrm{xg}$ and the resulting supernatant for $10 \mathrm{~min}$ at $6800 \mathrm{xg}$. The mitochondrial sediment was washed twice in the isolation medium without BSA and EGTA and suspended in the same medium. Isolated mitochondria were stored at $0{ }^{\circ} \mathrm{C}$. Mitochondrial swelling and other determinations were measured immediately after isolation; we did not use the mitochondria longer than two hours after isolation.

\section{Determination of mitochondrial swelling}

Mitochondrial swelling, as previously mentioned (Drahota et al. 2012a), was estimated as a decrease in the 
absorbance at $520 \mathrm{~nm}$ at $30^{\circ} \mathrm{C}$ in a Shimazu UV 160 spectrophotometer. The basic swelling medium contained $125 \mathrm{mM}$ sucrose, $65 \mathrm{mM} \mathrm{KCl}, 10 \mathrm{mM}$ HEPES, and $5 \mathrm{mM}$ succinate, with a $\mathrm{pH}$ of 7.2. K-phosphate, $\mathrm{T}_{3}$ and $\mathrm{Ca}^{2+}$ were added as indicated in the figures. One minute after mitochondria reached an absorbance of about 1 (amount $0.4 \mathrm{mg} / \mathrm{ml}$ ) swelling was induced by addition of $\mathrm{CaCl}_{2}$ solution. The decrease in absorbance was detected in $10 \mathrm{~s}$ intervals for a further $10 \mathrm{~min}$. We obtained three parameters of the swelling process in digital form: (a) the extent of the swelling $\left(\mathrm{dA}_{520} / 9 \mathrm{~min}\right)$; (b) the maximum swelling rate $\left(\mathrm{dA}_{520} / 10 \mathrm{~s}\right)$; (c) the time(s) required to reach the maximum rate.

Each figure is representative of at least 3 different experiments using different mitochondrial preparations; all experiments gave identical results.

\section{Determination of mitochondrial membrane potential}

The mitochondrial membrane potential $(\Delta \psi)$ was detected according to Wasilewski et al. (2004) using the cationic dye safranin O. Safranin O uptake by mitochondria (Akerman and Wikström 1976) was determined from fluorescence quenching monitored at wavelengths of $495 \mathrm{~nm}$ (excitation) and $586 \mathrm{~nm}$ (emission) with an AMINCO-Bowman Series 2 Luminescence Spectrometer. The measurement was performed in $1 \mathrm{ml}$ of a basic swelling medium containing $125 \mathrm{mM}$ sucrose, $65 \mathrm{mM} \mathrm{KCl}, 10 \mathrm{mM}$ HEPES, with a $\mathrm{pH}$ of 7.2. First, safranin $\mathrm{O}(10 \mu \mathrm{M})$, glutamate $(10 \mathrm{mM})$, malate $(2.5 \mathrm{mM})$ and mitochondria $(0.1 \mathrm{mg}$ prot. $/ 1 \mathrm{ml})$ were added to the medium. $\mathrm{T}_{3}$ and $\mathrm{Ca}^{2+}$ were added as indicated in the figures.

\section{Determination of proteins}

Protein content was determined by the Lowry et al. (1951) method using bovine serum albumin as a standard.

\section{Results}

For evaluating the $\mathrm{T}_{3}$ activation effect we selected concentrations of the main swelling inducer calcium ions that do not induce maximum values of the swelling rate and allow for the study of $\mathrm{T}_{3}$ activation. Figure 1 and Table 1 demonstrate that in the presence of $0.1 \mathrm{mM} \mathrm{K}$-phosphate, $50 \mu \mathrm{M} \mathrm{Ca}^{2+}$ yields a swelling rate of about $50 \%$ of the maximum value obtained at $200 \mu \mathrm{M}$ $\mathrm{Ca}^{2+}$. The extent of swelling nearly reaches maximum values with a slower decrease (see Table 1). We therefore used $50 \mu \mathrm{M} \mathrm{Ca}^{2+}$ in further experiments and compared the extent to which the combination of $\mathrm{T}_{3}$ with calcium and phosphate ions activates the rate of mitochondrial swelling.

Table 2 demonstrates the values of the swelling rate, the extent of swelling and the time required for the maximum swelling rate, which was extracted from classical swelling curves and curves obtained after their derivation (Fig. 2). It is evident that calcium alone increases spontaneous swelling about five-fold. Triiodothyronine activates spontaneous swelling about seven-fold and $0.1 \mathrm{mM}$ phosphate has practically no effect. Calcium induced swelling is activated by phosphate five-fold, while triiodothyronine provided only two-fold activation. However, calcium and phosphate induced swelling can be more than two-fold increased by triiodothyronine (see Table 2). These data thus indicate that $\mathrm{T}_{3}$ is directly involved in the regulation of MPTP.

We also tested the concentration dependence of the $\mathrm{T}_{3}$ activating effect on mitochondrial swelling in the absence of phosphate in the medium. As demonstrated in Figure 3 and summarized in Table 3, there was a very low calcium-induced swelling (in the absence of $\mathrm{T}_{3}$ ). Two-fold increases could be detected already at $1.25 \mu \mathrm{M}$ $\mathrm{T}_{3}$, and the highest activation was detected at a concentration range of $15-25 \mu \mathrm{M} \mathrm{T}_{3}$.

We also confirmed previous literature findings (Kalderon et al. 1995, Yehuda-Shnaidman et al. 2010) that $\mathrm{T}_{3}$ activation of $\mathrm{CaCl}_{2}$-induced swelling can be detected in isolated mitochondria after in vivo application of $\mathrm{T}_{3}$ (Fig. 4 and Table 4). After one dose of $\mathrm{T}_{3}$ the swelling rate reached $169 \%$ of the control values and after three applications $198 \%$. The extent of swelling was increased by one dose of $\mathrm{T}_{3}(143 \%)$; after three doses of $\mathrm{T}_{3}$ we did not see any additional increase in the extent of swelling (Table 4).

Triiodothyronine activation of mitochondrial swelling measured under conditions giving the maximal values of the swelling rate was completely inhibited by cyclosporine A (Fig. 5). These data also confirm a direct effect of $\mathrm{T}_{3}$ on the functional activity of mitochondrial membrane permeability transition pore.

As an additional support for a direct $\mathrm{T}_{3}$ action on the mitochondrial membrane permeability transition pore, we tested its effect on the dissipation of mitochondrial membrane potential induced by $50 \mu \mathrm{M} \mathrm{CaCl}_{2}$. Changes in mitochondrial membrane potential were measured by a safranin O fluorescent probe. Our data (Fig. 6) showed that the decrease in the membrane potential induced by 

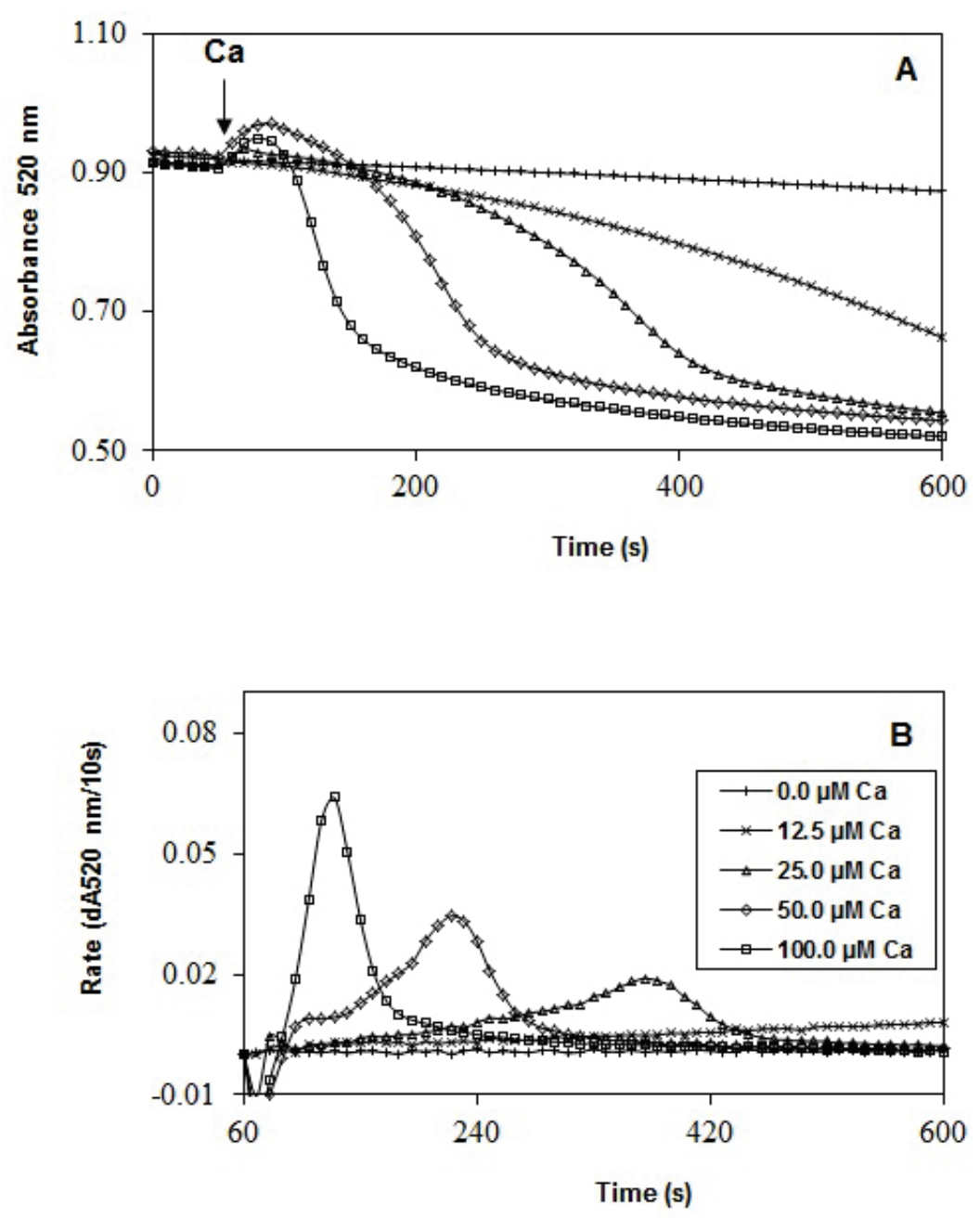

Fig. 1. Calcium dependent swelling of rat liver mitochondria. A: Classical swelling curves, B: Swelling curves after derivation. Mitochondria $(0.4 \mathrm{mg} / \mathrm{ml})$ were incubated in the basic swelling medium with $0.1 \mathrm{mM}$ $\mathrm{K}$-phosphate. After one minute of incubation $\mathrm{CaCl}_{2}$ was added.

Table 1. Calcium induced swelling of rat liver mitochondria.

\begin{tabular}{|c|c|c|c|}
\hline $\begin{array}{l}\text { Additions } \\
\left(\mu \mathrm{M} \mathrm{Ca}^{2+}\right)\end{array}$ & $\begin{array}{c}\text { Swelling rate } \\
\left(\mathbf{d A}_{\mathbf{5 2 0}} / \mathbf{1 0 s}\right)\end{array}$ & $\begin{array}{l}\text { Extent of swelling } \\
\qquad\left(\mathrm{dA}_{520} / 9 \mathrm{~min}\right)\end{array}$ & $\begin{array}{c}\text { Time of maximum swelling } \\
\text { (seconds after swelling } \\
\text { induction) }\end{array}$ \\
\hline 0 & $0.0010(1 \%)$ & $0.0450(11 \%)$ & 540 \\
\hline 5 & $0.0012(2 \%)$ & $0.0582(15 \%)$ & 540 \\
\hline 12.5 & $0.0081(11 \%)$ & $0.2516(65 \%)$ & 540 \\
\hline 25 & $0.0191(26 \%)$ & $0.3687(93 \%)$ & 310 \\
\hline 50 & $0.0345(47 \%)$ & $0.3991(100 \%)$ & 160 \\
\hline 100 & $0.0639(87 \%)$ & $0.4012(101 \%)$ & 70 \\
\hline 150 & $0.0739(101 \%)$ & $0.3954(100 \%)$ & 60 \\
\hline 200 & $0.0731(100 \%)$ & $0.3969(100 \%)$ & 60 \\
\hline
\end{tabular}

Data presented were extracted from the swelling curves in Figure 1. The changes of swelling rate and extent of swelling are expressed in absolute values $\left(\mathrm{dA}_{520} / 10 \mathrm{~s}\right)$ and $\left(\mathrm{dA}_{520} / 9 \mathrm{~min}\right)$. For better clarity, the results were expressed also as a percentage of values obtained at $200 \mu \mathrm{M} \mathrm{Ca}^{2+}(100 \%)$.

calcium can be further potentiated by $\mathrm{T}_{3}$ in a manner similar to the swelling experiments. $\mathrm{T}_{3}$ can activate the dissipation of the membrane potential even in the absence of calcium ions.

We may thus conclude that our data indicate that in the absence of calcium and phosphate ions $\mathrm{T}_{3}$ alone 


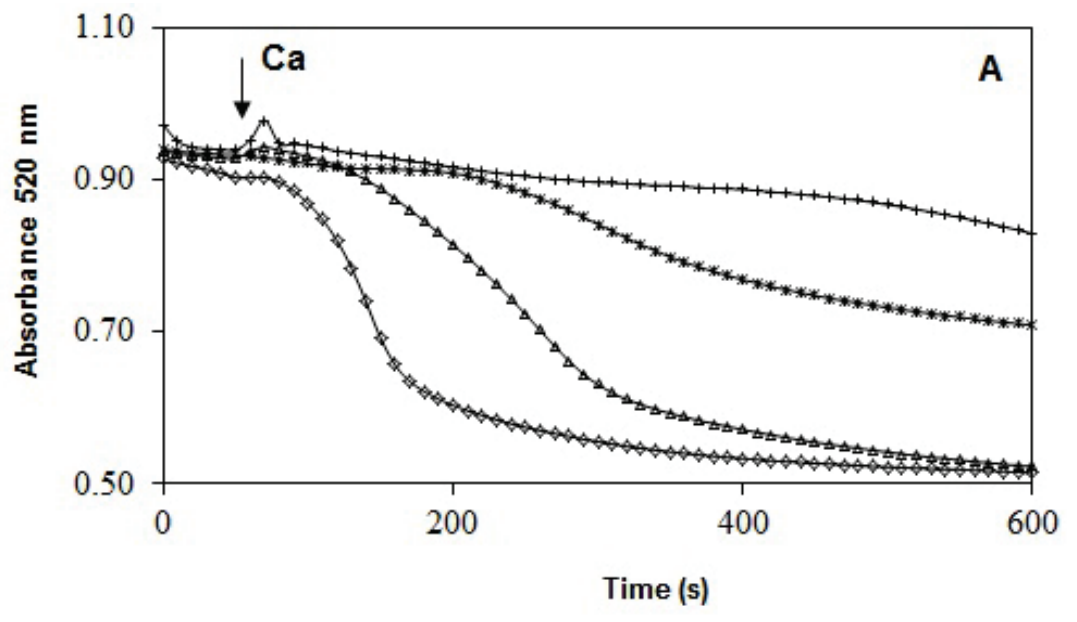

Fig. 2. The effect of calcium, phosphate and triiodothyronine interactions on swelling of rat liver mitochondria. Mitochondria $(0.4 \mathrm{mg}$ protein/ml) were incubated in basic swelling medium with $0.1 \mathrm{mM}$ K-phosphate or $25 \mu \mathrm{M}$ $T_{3}$ or with phosphate and $T_{3}$ as indicated. $T_{3}$ was added immediately after mitochondria; $50 \mu \mathrm{M} \mathrm{Ca}{ }^{2+}$ was added after $60 \mathrm{~s}$ of incubation.

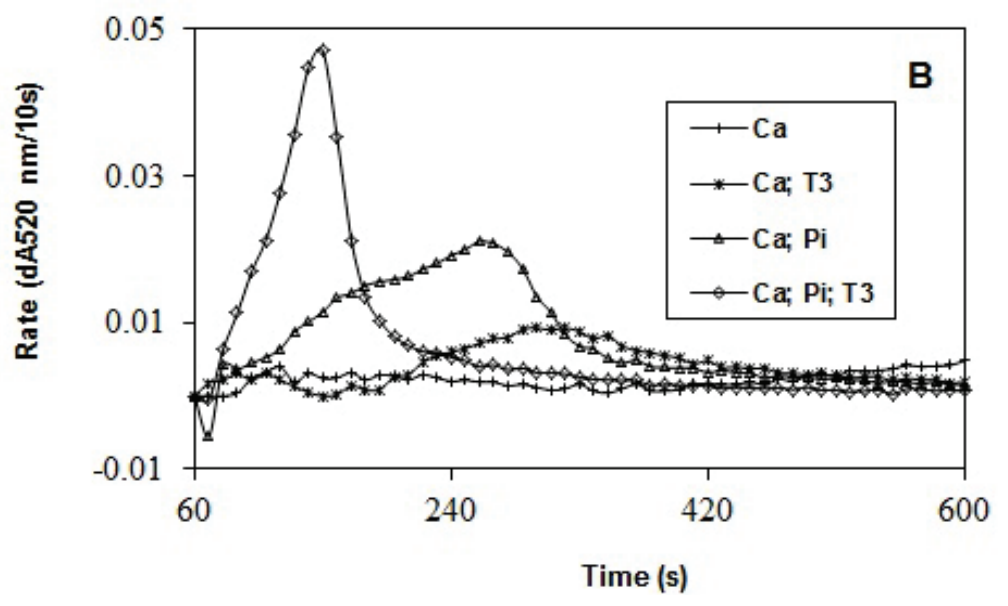

Table 2. Maximum swelling rate: calcium, phosphate and triiodothyronine interactions.

\begin{tabular}{lccc}
\hline Additions & $\begin{array}{c}\text { Swelling rate } \\
\left(\mathbf{d} \mathbf{A}_{\mathbf{5 2 0}} / \mathbf{1 0 s}\right)\end{array}$ & $\begin{array}{c}\text { Extent of swelling } \\
\left.\mathbf{( d A}_{\mathbf{5 2 0}} / \mathbf{9 m i n}\right)\end{array}$ & $\begin{array}{c}\text { Time of maximum swelling } \\
\text { (seconds after swelling } \\
\text { induction) }\end{array}$ \\
\hline No additions & 0.0009 & 0.0173 & 480 \\
$50 \mu M \mathrm{Ca}^{2+}$ & 0.0042 & 0.1229 & 500 \\
$25 \mu \mathrm{MT} T_{3}$ & 0.0065 & 0.2186 & 210 \\
$0.1 \mathrm{mMP} P_{i}$ & 0.0014 & 0.0450 & 390 \\
$P_{i}+T_{3}$ & 0.0128 & 0.2781 & 150 \\
$\mathrm{Ca}^{2+}+T_{3}$ & 0.0093 & 0.2216 & 240 \\
$\mathrm{Ca}^{2+}+P_{i}$ & 0.0211 & 0.4143 & 200 \\
$\mathrm{Ca}^{2+}+P_{i}+T_{3}$ & 0.0471 & 0.3846 & 90
\end{tabular}

Data presented were extracted from swelling curves presented in Figure 2.

may activate mitochondrial swelling and the rate of this process is further increased by calcium and phosphate. We also confirmed findings of previous experiments (Červinková et al. 1998) showing that the activating effect of $\mathrm{T}_{3}$ may be detected in isolated mitochondria after the in vivo application of triiodothyronine. Using a safranin $\mathrm{O}$ fluorescent probe we confirmed the data obtained in the swelling experiments by demonstrating that $25 \mu \mathrm{M} \mathrm{T} \mathrm{T}_{3}$ accelerates the discharge of the membrane potential induced by calcium ions. 


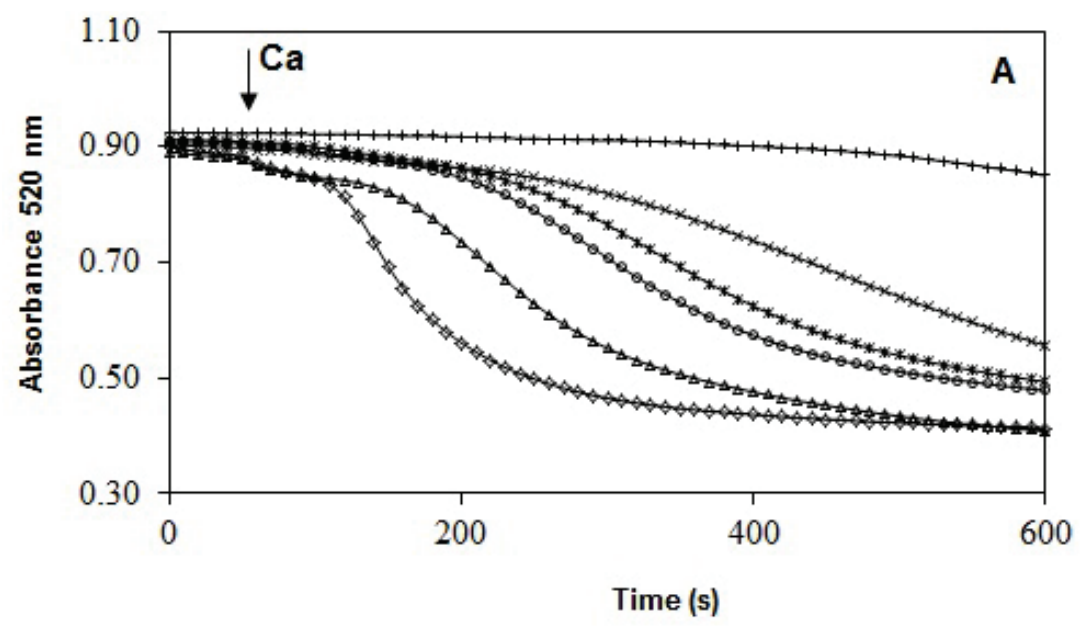

Fig. 3. The effect of $T_{3}$ on swelling of rat liver mitochondria. Mitochondria were incubated in the basic swelling medium without phosphate. $\mathrm{T}_{3}$ was added immediately after mitochondria. Swelling was started by the addition of $50 \mu \mathrm{M} \mathrm{Ca}{ }^{2+}$ after $60 \mathrm{~s}$ of incubation.

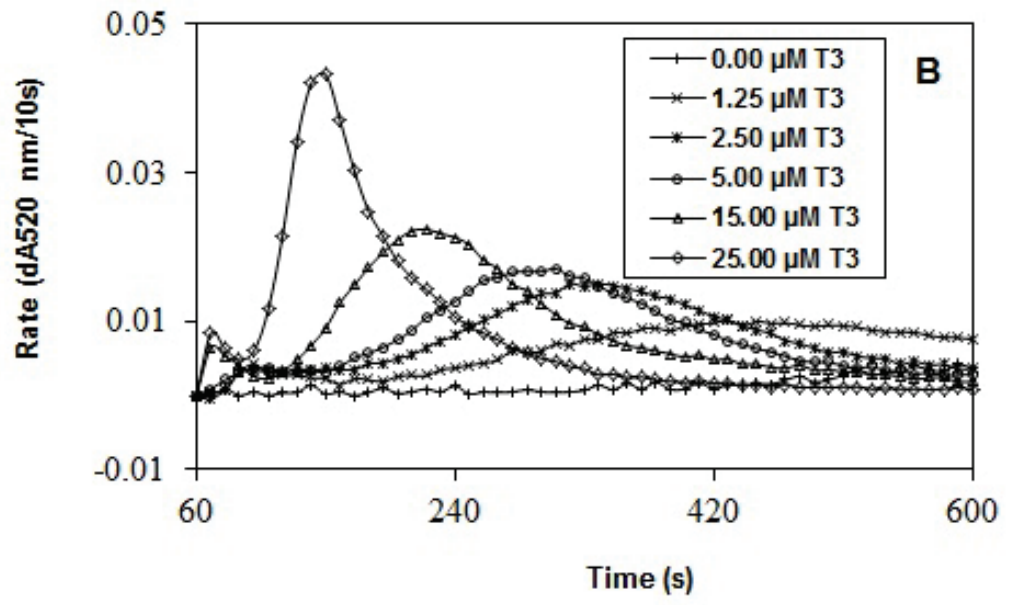

Table 3. The effect of $T_{3}$ on swelling of rat liver mitochondria.

\begin{tabular}{lccc}
\hline $\begin{array}{l}\text { Additions } \\
\left(\boldsymbol{\mu M} \mathbf{T}_{\mathbf{3}}\right)\end{array}$ & $\begin{array}{c}\text { Swelling rate } \\
\left(\mathbf{d} \mathbf{A}_{\mathbf{5 2 0}} / \mathbf{1 0 s}\right)\end{array}$ & $\begin{array}{c}\text { Extent of swelling } \\
\left(\mathbf{d A}_{\mathbf{5 2 0}} / \mathbf{9 m i n}\right)\end{array}$ & $\begin{array}{c}\text { Time of maximum swelling } \\
\text { (seconds after swelling } \\
\text { induction) }\end{array}$ \\
\hline 0 & $0.0042(10 \%)$ & $0.0730(16 \%)$ & 530 \\
1.25 & $0.0101(23 \%)$ & $0.3388(74 \%)$ & 370 \\
2.5 & $0.0151(35 \%)$ & $0.4128(90 \%)$ & 260 \\
5 & $0.0171(39 \%)$ & $0.4234(92 \%)$ & 250 \\
15 & $0.0224(52 \%)$ & $0.4573(100 \%)$ & 90 \\
\hline
\end{tabular}

Data in the table were extracted from Figure $3 \mathrm{~A}, \mathrm{~B}$. The changes of swelling rate and extent of swelling are expressed in absolute values $\left(\mathrm{dA}_{520} / 10 \mathrm{~s}\right)$ and $\left(\mathrm{dA}_{520} / 9 \mathrm{~min}\right)$. For better clarity, the results were expressed also as a percentage of values obtained at $25 \mu \mathrm{M} \mathrm{T}_{3}$ (100\%).

\section{Discussion}

In our experiments we tried to obtain additional data that could help to characterize better the role of $\mathrm{T}_{3}$ in activating the MPTP opening. Previous data in literature has supported the claim that the $T_{3}$ activating effect is indirect due to an increase in the sensitivity of the pore to calcium ions through the mechanism of ROS generation (Castilho et al. 1998). Our data showed that if $\mathrm{Ca}^{2+}, \mathrm{P}_{\mathrm{i}}$ or $\mathrm{T}_{3}$ are added separately to mitochondria, both $\mathrm{Ca}^{2+}$ and $\mathrm{T}_{3}$ 


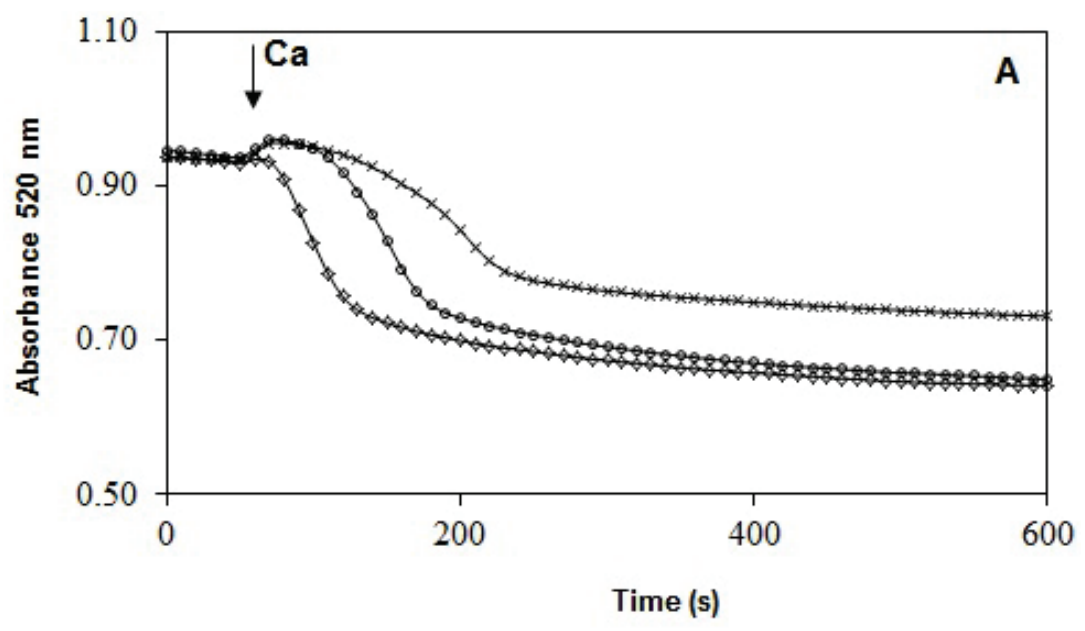

Fig. 4. Swelling of isolated rat liver mitochondria after in vivo intraperitoneal application of $\mathrm{T}_{3} . \mathrm{T}_{3}$ was applied $1 \times 200 \mu \mathrm{g} / \mathrm{kg}$ body weight or $3 \times 200 \mu \mathrm{g} / \mathrm{kg}$ body weight. Isolated mitochondria were incubated in the basic swelling medium with $0.1 \mathrm{mM}$ K-phosphate. Swelling was started by the addition of $50 \mu \mathrm{M} \mathrm{Ca}^{2+}$.

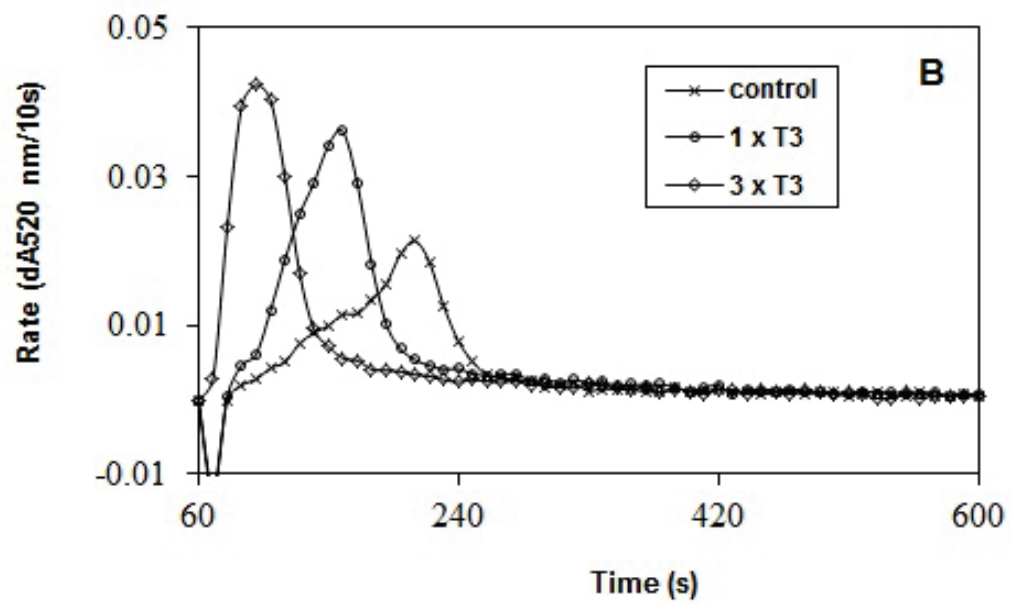

Table 4. The effect of $T_{3}$ applied in vivo on swelling of isolated mitochondria.

\begin{tabular}{lccc}
\hline $\begin{array}{l}\text { Additions } \\
\left(\boldsymbol{\mu M} \mathbf{~ T}_{\mathbf{3}}\right)\end{array}$ & $\begin{array}{c}\text { Swelling rate } \\
\left(\mathbf{d} \mathbf{A}_{\mathbf{5 2 0}} / \mathbf{1 0 s}\right)\end{array}$ & $\begin{array}{c}\text { Extent of swelling } \\
\left(\mathbf{d A}_{\mathbf{5 2 0}} / \mathbf{9 m i n}\right)\end{array}$ & $\begin{array}{c}\text { Time of maximum swelling } \\
\text { (seconds after swelling } \\
\text { induction) }\end{array}$ \\
\hline Control & $0.0214(100 \%)$ & 0.2062 & 150 \\
$1 x T_{3}$ & $0.0361(169 \%)$ & 0.2954 & 100 \\
$3 x T_{3}$ & $0.0424(198 \%)$ & 0.2953 & 40 \\
\hline
\end{tabular}

Data presented were extracted from swelling curves in Figure 4.

induce a nearly five-fold increase in the swelling rate, whereas phosphate ions fail to. Phosphate, however, activates both $\mathrm{Ca}^{2+}$ as well as $\mathrm{T}_{3}$ induced rates. The activation of the $\mathrm{Ca}^{2+}$ rate was about two-fold higher. The highest swelling rate was observed when all three factors were present (Table 2). This indicates that calcium and phosphate ions cannot reach the maximum swelling rate without $T_{3}$. We may conclude that calcium-induced swelling is more activated by phosphate (five-fold) than by $\mathrm{T}_{3}$ (two-fold), but that the $\mathrm{Ca}^{2+}$ and $\mathrm{P}_{\mathrm{i}}$ induced swelling rate can be further (two-fold) increased by $\mathrm{T}_{3}$. As evident from Figure 2, $\mathrm{T}_{3}$ accelerates the maximum swelling rate, but the maximum extent of swelling attains approximately the same values during the incubation period. This indicates that the membrane's capacity to swell is not changed by the presence of $\mathrm{T}_{3}$.

We confirmed the findings of previous literature (Kalderon et al. 1995) which showed that the swelling 

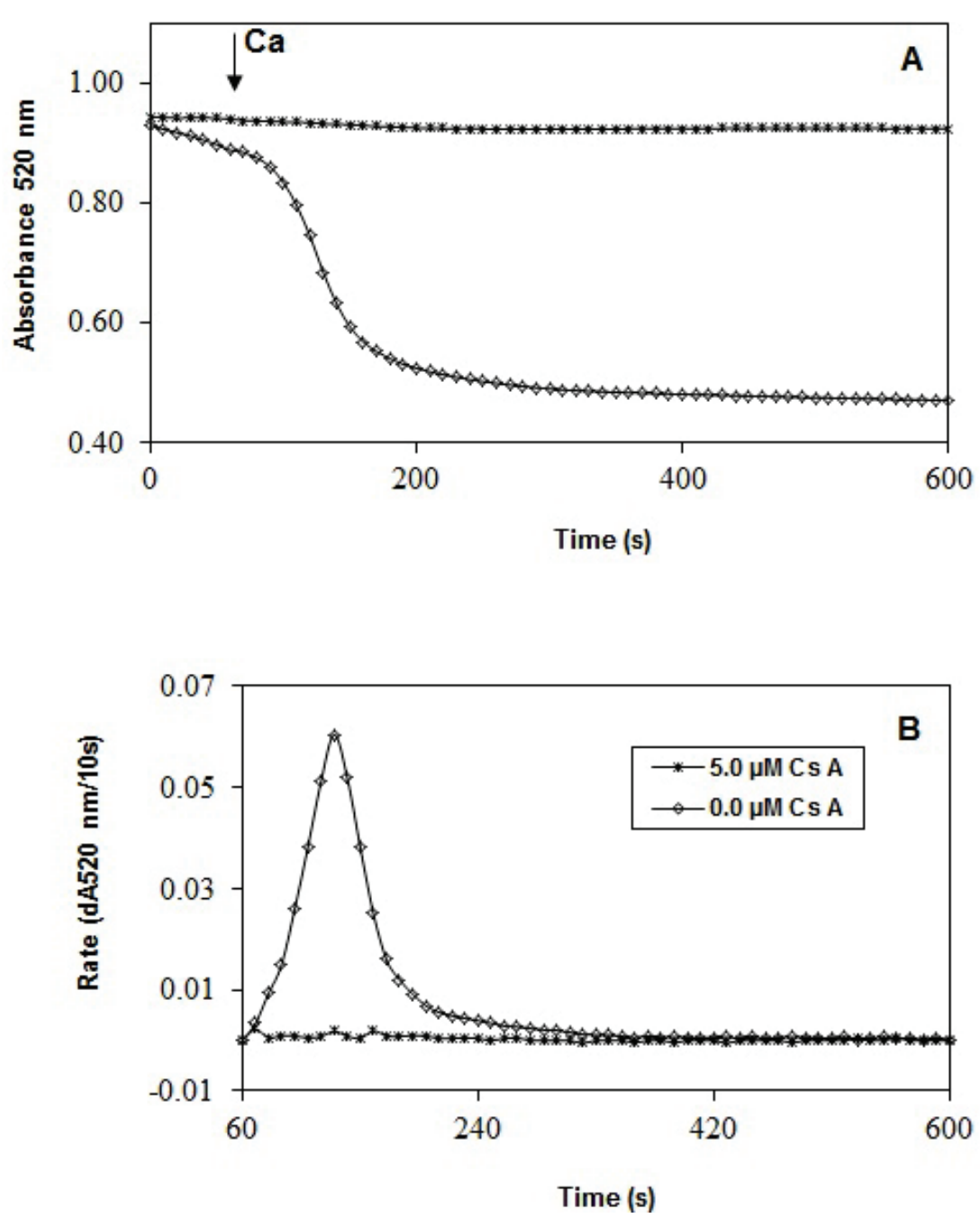

Fig. 5. Inhibition of mitochondrial swelling induced by $\mathrm{Ca}^{2+}$ and activated by $25 \mu \mathrm{M} \mathrm{T}$ by CsA. Mitochondria were incubated in the basic swelling medium as in Figure 1. $25 \mu \mathrm{M}$ $\mathrm{T}_{3}$ and $1 \mu \mathrm{M}$ CsA were added after mitochondria. $50 \mu \mathrm{M} \mathrm{Ca}{ }^{2+}$ was added after $60 \mathrm{~s}$ of incubation. activation by $\mathrm{T}_{3}$ can also be observed with isolated mitochondria after the in vivo application of $\mathrm{T}_{3}$. This indicates that triiodothyronine can induce changes in MPTP properties that may be observed after isolating mitochondria.

We may thus conclude that applying the derivation of the swelling curves used in this study gives us more information about the swelling process and how various activating factors are involved in the regulation of swelling.

However, for an understanding of the detailed mechanisms through which the opening and closing of MPTP is regulated, more data are still required. There are indications that differences in Ca-induced swelling exist in mitochondrial subpopulations (Saunders et al. 2013). These authors stained mitochondria from rabbit kidneys with molecular probes for cardiolipin content and membrane potential and analyzed using flow cytometry. They found that these subpopulations with different cardiolipin content showed differences in membrane potential, volume, and responses to uncoupling and calcium-induced swelling.

After elucidating the mechanism of pore function and its regulation it will be possible to answer many questions in the various fields of biomedical research since it has been demonstrated that this pore is involved in the pathogenesis of diseases such as cardiomyopathies, neuropathies, liver diseases (Bernardi and Di Lisa 2015, Bonora et al. 2015, Traba et al. 2012) as well as in the process of ageing (Moro et al. 2004). Regulating the function of MPTP could help in the treatment of these diseases.

\section{Conflict of Interest}

There is no conflict of interest.

\section{Acknowledgements}

This study was supported by the Program PRVOUK P37/02 and grant 1436804G from the Grant Agency of the Czech Republic. We would like to thank to Matthew Shane Renfro for language review. 


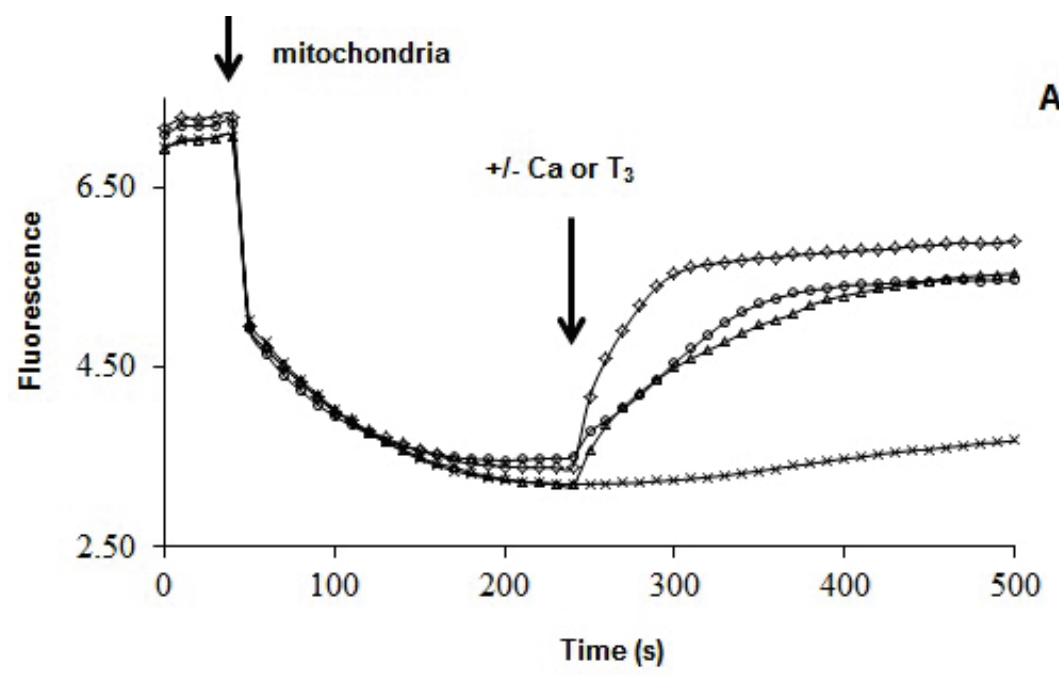

Fig. 6. $T_{3}$-activated changes of mitochondrial membrane potential. Membrane potential

A measured as described in Methods.

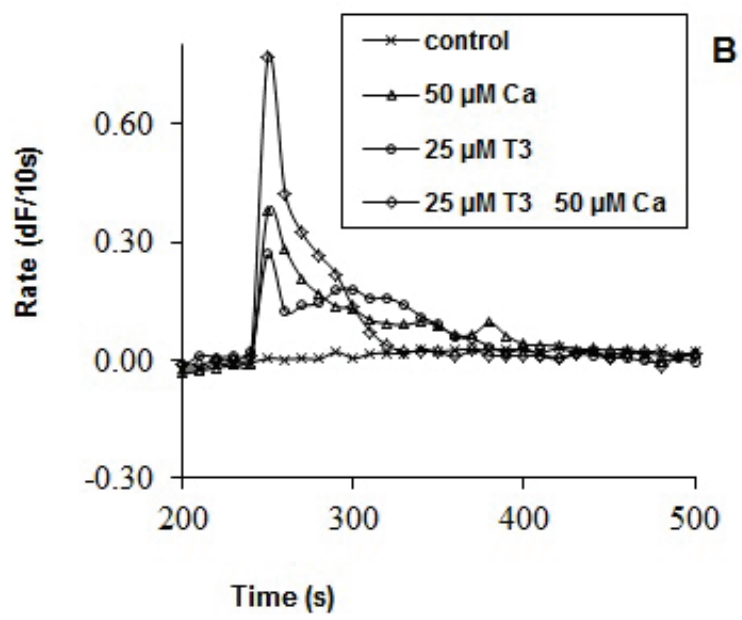

\section{References}

AKERMAN KE, WIKSTRÖM MK: Safranine as a probe of the mitochondrial membrane potential. FEBS Lett 68: 191197, 1976.

ALAVIAN KN, BEUTNER G, LAZROVE E, SACCHETTI S, PARK H-A, LICZNERSKI P, LI H., NABILI P, HOCKENSMITH K, GRAHAM M, PORTER GA Jr, JONAS EA: An uncoupling channel within the c-subunit ring of the $\mathrm{F}_{1} \mathrm{~F}_{\mathrm{o}}$ ATP synthase is the mitochondrial permeability transition pore. Proc Natl Acad Sci USA 111: 10580-10585, 2014.

BERNARDI P, DI LISA F: The mitochondrial permeability transition pore: molecular nature and role as a target in cardioprotection. J Mol Cell Cardiol 78: 100-106, 2015.

BONORA M, WIECKOWSKI MR, CHINOPOULOS C, KEPP O, KROMER G, GALLUZI L, PINTON P: Molecular mechanisms of cell death: central implication of ATP synthase in mitochondrial permeability transition. Oncogene 34: 1475-1486, 2015.

CASTILHO RF, KOWALTOWSKI AJ, VERCESI AE: 3,5,3'-triiodothyronine induces mitochondrial permeability transition mediated by reactive oxygen species and membrane protein thiol oxidation. Arch Biochem Biophys 354: 151-157, 1998.

ČERVINKOVÁ Z, SVÁTKOVÁ R, KALOUS M, RAUCHOVÁ H, ČERVINKA M, DRAHOTA Z: Effect of triiodothyronine administration on the recovery of liver oxidative capacity after partial hepatectomy. Eur Surg Res 30: 371-377, 1998. 
CHENG S-Y, LEONARD JL, DAVIS PJ: Molecular aspects of thyroid hormone actions. Endocr Rev 31: 139-170, 2010.

CROMPTON M, ELLINGER H, COSTI A: Inhibition by cyclosporine A of a $\mathrm{Ca}^{2+}$-dependent pore in heart mitochondria activated by inorganic phosphate and oxidative stress. Biochem J 255: 357-360, 1988.

DAVIS PJ, DAVIS FB: Nongenomic action of thyroid hormone. Thyroid 6: 497-506, 1996.

DRAHOTA Z, ENDLICHER R, STAŇKOVÁ P, RYCHTRMOC D, MILEROVÁ M, ČERVINKOVÁ Z: Characterization of calcium, phosphate and peroxide interactions in activation of mitochondrial swelling using derivative of swelling curves. J Bioenerg Biomembr 44: 309-315, 2012 a.

DRAHOTA Z, MILEROVÁ M, ENDLICHER R, RYCHTRMOC D, ČERVINKOVÁ Z, OŠŤÁDAL B: Developmental changes of the sensitivity of cardiac and liver mitochondrial permeability transition pore to calcium load and oxidative stress. Physiol Res 61(Suppl 1): S165-S172, 2012b.

DRAHOTA Z, PALENICKOVA E, ENDLICHER R, MILEROVA M, BREJCHOVA J, VOSAHLIKOVA M, SVOBODA P, KAZDOVA L, KALOUS M, CERVINKOVA Z, CAHOVA M.: Biguanides inhibit complex I, II and IV of rat liver mitochondria and modify their functional properties. Physiol Res 63: 1-11, 2014.

FONTAINE E, ERIKSSON O, ICHAS F, BERNARDI P: Regulation of the permeability transition pore in skeletal muscle mitochondria. Modulation by electron flow through the respiratory chain complex I. J Biol Chem 273 : 12662-12668, 1998.

GUERRIERI F, KALOUS M, ADORISIO E, TURTURRO N, SANTORO G, DRAHOTA Z, CANTATORE P: Hypothyroidism leads to a decreased expression of mitochondrial F0F1-ATP synthase in rat liver. J Bioenerg Biomembr 30: 269-276, 1998.

GUTIÉRREZ-AGUILAR M, DOUGLAS DL, GIBSON AK, DOMEIER TL, MOLKENTIN JD, BAINES CP: Genetic manipulation of the cardiac mitochondrial phosphate carrier does not affect permeability transition. $J$ Mol Cell Cardiol 72: 316-325, 2014.

HALESTRAP AP, RICHARDSON A: The mitochondrial permeability transition: a current perspective on its identity and role in ischemia/reperfusion injury. J Mol Cell Cardiol 78: 129-141, 2015.

HARPER ME, SEIFERT EL: Thyroid hormone effects on mitochondrial energetics. Thyroid 18: 145-156, 2008.

KALDERON B, HERMESH O, BAR-TANA J: Mitochondrial permeability transition is induced by in vivo thyroid hormone treatment. Endocrinology 136: 3552-3556, 1995.

KARCH J, MOLKENTIN JD: Identifying the components of the elusive mitochondrial permeability transition pore. Proc Natl Acad Sci USA 111: 10396-10397, 2014.

KOKOSZKA JE, WAYMIRE KG, LEVY SE, SLIGH JE, CAI J, JONES DP, MACGREGOR GR, WALLACE DC: The ADP/ATP translocator is not essential for the mitochondrial permeability transition pore. Nature 427: 461465, 2004.

LANNI A, MORENO M, LOMBARDI A, DE LANGE P, GOGLIA F: Control of energy metabolism by iodothyronines. J Endocrinol Invest 24: 897-913, 2001.

LEHNINGER AL: Thyroxine and the swelling and contraction cycle in mitochondria. Ann NY Acad Sci 86: 484-493, 1960.

LOWRY OH, ROSEBROUGH NJ, FARR AL, RANDALL RJ: Protein measurement with the folin phenol reagent. J Biol Chem 193: 265-275, 1951.

MILEROVA M, CHARVATOVA Z, SKARKA L, OSTADALOVA I, DRAHOTA Z, FIALOVA M, OSTADAL B: Neonatal cardiac mitochondria and ischemia/reperfusion injury. Mol Cell Biochem 335: 147-153, 2010.

MORO L, MARRA E, CAPUANO F, GRECO M: Thyroid hormone treatment of hypothyroid rats restores the regenerative capacity and the mitochondrial membrane permeability properties of the liver after partial hepatectomy. Endocrinology 145: 5121-5128, 2004.

MRÁČEK T, JEŠINA P, KŘIVÁKOVÁ P, BOLEHOVSKÁ R, ČERVINKOVÁ Z, DRAHOTA Z, HOUŠTĚK J: Time-course of hormonal induction of mitochondrial glycerophosphate dehydrogenase biogenesis in rat liver. Biochim Biophys Acta 1726: 217-223, 2005.

RAAFLAUB J: Swelling of isolated mitochondria. Helv Physiol Pharmacol Acta 11: 142-156, 1953.

RASOLA A, BERNARDI P: Mitochondrial permeability transition in $\mathrm{Ca}^{2+}$-dependent apoptosis and necrosis. Cell Calcium 50: 222-233, 2011. 
SAUNDERS JE, BEESON CC, SCHNELLMANN RG: Characterization of functionally distinct mitochondrial subpopulations. J Bioenerg Biomembr 45: 87-99, 2013.

TAPLEY DF: The effect of thyroxine and other substances on the swelling of isolated rat liver mitochondria. $J$ Biol Chem 222: 325-339, 1956.

TRABA J, DEL ARCO A, DUCHEN MR, SZABADKAI G, SATRÚSTEGUI J: SCaMC-1 promotes cancer cell

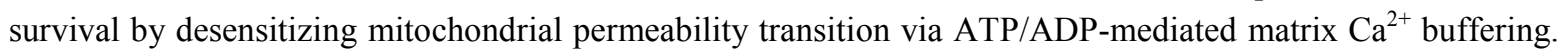
Cell Death Differ 19: 650-660, 2012.

VENDITTI P, DE ROSA R, Di MEO S: Effect of thyroid state on susceptibility to oxidants and swelling of mitochondria from rat tissues. Free Radic Biol Med 35: 485-494, 2003.

VIANELLO A, CASOLO V, PETRUSSA E, PERESSON C, PATUI S, BERTOLINI A, PASSAMONTI S, BRAIDOT E, ZANCANI M: The mitochondrial permeability transition pore (PTP) - an example of multiple molecular exaptation? Biochim Biophys Acta 1817: 2072-2086, 2012.

WASILEWSKI M, WIECKOWSKI MR, DYMKOWSKA D, WOJTCZAK L: Effects of N-acylethanolamines on mitochondrial energetics and permeability transition. Biochim Biophys Acta 1657: 151-163, 2004.

YEHUDA-SHNAIDMAN E, KALDERON B, AZAZMEH N, BAR-TANA J: Gating of the mitochondrial permeability transition pore by thyroid hormone. FASEB J 24: 93-104, 2010.

YEHUDA-SHNAIDMAN E, KALDERON B, BAR-TANA J: Thyroid hormone, thyromimetics, and metabolic efficiency. Endocr Rev 35: 35-58, 2014.

ZHANG J, LAZAR MA: The mechanism of action of thyroid hormones. Annu Rev Physiol 62: 439-466, 2000. 